Article

\title{
Synthesis of Anchored Bimetallic Catalysts via Epitaxy
}

\author{
Jiaxin Liu ${ }^{1,2}$, Botao Qiao ${ }^{1,3}$, Yian Song ${ }^{1}$, Yudong Huang ${ }^{2}$ and Jingyue (Jimmy) Liu ${ }^{1, *}$ \\ 1 Department of Physics, Arizona State University, Tempe, AZ 85287, USA; liujiaxin@hit.edu.cn (J.L.); \\ bqiao@dicp.ac.cn (B.Q.); yian.song@asu.edu (Y.S.) \\ 2 School of Chemistry and Chemical Engineering, Harbin Institute of Technology, Harbin 150001, China; \\ ydhuang.hit1@aliyun.com \\ 3 State Key Laboratory of Catalysis, Dalian Institute of Chemical Physics, Chinese Academy of Sciences, \\ Dalian 116023, China \\ * Correspondence: jingyue.liu@asu.edu; Tel.: +1-480-965-9731
}

Academic Editor: John R. (JR) Regalbuto

Received: 15 March 2016; Accepted: 9 June 2016; Published: 17 June 2016

\begin{abstract}
The development of thermodynamically stable supported bimetallic catalysts for high-temperature reaction is significant and highly desirable but remains a grand challenge. In this work, we report a novel approach that relies on the interaction of metal nanoparticles with the support material to form unique bimetallic nanoparticles, which epitaxially anchor onto the support surface. Such unique nanostructured systems are catalytically active and ultrastable during selected catalytic reactions. In this paper, we describe the synthesis processes of ultrastable PtZn nanoparticles epitaxially anchored onto $\mathrm{ZnO}$ nanowires, which primarily consist of $\{10-10\}$ nanoscale facets. Such anchored PtZn nanoparticles demonstrated good stability during high temperature treatments and selected catalytic reactions. The synthesis approach reported in this work provides a new strategy to develop thermodynamically stable supported bimetallic catalysts.
\end{abstract}

Keywords: bimetallic nanoparticle; epitaxy; nanowire; $\mathrm{ZnO}$; catalysts; electron microscopy

\section{Introduction}

Supported bimetallic catalysts have drawn attention in heterogeneous catalysis research due to, compared with their monometallic counterparts, their superior catalytic properties [1]. Bimetallic nanoparticles have been studied in several important chemical reactions [2]. The impregnation method is commonly used for the synthesis of bimetallic catalysts because of its simplicity. However, nanoparticles produced using such an approach usually have inherently non-uniform sizes and/or compositions. The uncertainty about the composition and size of the synthesized bimetallic nanoparticles makes it difficult to establish meaningful structure-reactivity relationships [3,4]. It is thus imperative to exploit novel synthesis strategies that produce supported bimetallic nanoparticles with specific compositions and ultrastability. Several new types of catalyst synthesis methods have been developed to ensure appropriate metal-metal interaction to form the compositions of each nanoparticle. For example, electroless deposition [5-7] and strong electrostatic adsorption [8-12] approaches have been extensively studied.

An inherent problem for developing nanocatalysts, especially bimetallic or multimetallic nanoparticle based catalysts, is their lack of stability under practical catalytic reaction conditions [13,14]. Supported metal/alloy nanoparticles experience rapid growth during their use, especially at elevated reaction temperatures [15]. Such sintering effect decreases the number of surface active sites and consequently leads to deactivation of the nanocatalysts of interest. In order to maintain the sizes of 
the metal/alloy nanoparticles during catalytic reactions, it is highly desirable to strongly anchor the metal/alloy nanoparticles onto the surfaces of the support materials.

Heteroepitaxy, the oriented growth of one crystal/film on another with certain crystallographic orientation relationship, has been extensively studied in surface science and semiconductor fields [16]. It is expected that the enhanced interfacial adhesion between an epitaxially grown metal nanoparticle and a well-defined nanoscale facet of the support can inhibit, or at least reduce, sintering of metal/alloy nanoparticles caused by particle migration and coalescence processes. To grow all metal nanoparticles epitaxially in a supported metal catalyst requires the fabrication of support materials that possess the same or similar surface structure. When such high-surface-area crystalline supports are synthesized, it is possible to grow all metal/alloy nanoparticles epitaxially with the same type of interfacial structure and most likely with the same or similar shape, which is important for the fundamental study of the structure-performance relationships of supported metal/alloy nanoparticle catalysts.

Epitaxial growth of metals on clean and flat substrates has been researched for many years. For instance, metals can epitaxially grow on metal oxides through atomic layer deposition [15], pulsed laser deposition [17], UHV sputtering deposition [18-21], and annealing [22]. Unfortunately, vapor-phase deposition techniques suffer from several disadvantages, such as the requirement of ultra-high vacuum conditions and the use of special equipment [23]. Furthermore, most of the vapor-phase deposition techniques only work for planar surfaces and cannot be applied to deposit metal/alloy nanoparticles onto high-surface-area supports. The wet chemistry synthetic route remains the main method for producing supported metal/alloy nanocatalysts due to its relatively low cost, easy-operation, versatility, and scalability [24].

We have now developed a general strategy to synthesize ultrastable nanostructured metal/alloy catalysts by using the recent advancement in controllable synthesis of nanostructured support materials. In this paper, we illustrate this general synthesis method for fabricating $\mathrm{ZnO}$ nanowire supported PtZn nanoalloy catalysts. PtZn alloy nanoparticles have been synthesized through many methods including the reaction of $\mathrm{Zn}$ vapor with Pt particles supported on carbon [25], electrodeposition of $\mathrm{Zn}$ onto $\mathrm{Pt}$ particles [26], and heating $\mathrm{Pt}$ particles on $\mathrm{ZnO}$ supports under a reducing atmosphere [27-30]. A recent review article published by Long et al. [31] gives an elaborate survey of the development of Pt-based catalysts, the important role of the structure, size, shape, and morphology of Pt nanoparticles, and their applications for energy conversion.

In this work, we selected highly stable $\mathrm{ZnO}$ nanowires that primarily consist of low-energy and stable $\{10-10\}$ nanoscale facets. Successful synthesis of epitaxially anchored PtZn nanoparticles onto $\mathrm{ZnO}$ nanowires depends on (1) the cleanness and flatness of the $\mathrm{ZnO}\{10-10\}$ nanoscale facets; (2) the uniform deposition of the Pt precursor species onto the $\mathrm{ZnO}\{10-10\}$ facets; and (3) the control of the reduction processes to promote the formation and epitaxial growth of PtZn nanoparticles on the $\mathrm{ZnO}$ $\{10-10\}$ facets. When these processes are optimized, epitaxially anchored PtZn bimetallic nanoparticles can be reliably and repeatedly produced. We have tested the synthesized PtZn/ZnO nanocatalysts for water-gas-shift (WGS) reaction and attributed their long-term stability to the epitaxial anchoring of the PtZn nanoparticles.

\section{Results and Discussion}

The preparation processes of supported metal/alloy nanoparticle catalysts generally consists of three steps: (1) contact of a metal precursor with the support material; (2) oxidation/calcination of the metal precursor/support composite to eliminate the undesirable molecular species; and (3) formation of the active nanoparticles via various types of reduction processes. It is usually during the reduction step that the metal/alloy nanoparticles evolve into their thermodynamically stable shapes and size distributions. Importantly, the reduction step often leads to a wide distribution of nanoparticles or nanoalloys with non-uniform composition. Furthermore, during the reduction processes, the surface structure and chemistry of the support materials may be modified which in turn can significantly affect the characteristics of the supported metal/alloy nanoparticles. Precise and careful control of the 
metal precursor distribution and the movement of the metal atoms during the reduction processes is essential to preparing supported nanoparticle catalysts with size-, shape- and composition-control.

Deposition-precipitation is a common method for preparing supported metal/alloy catalysts where the metal precursor complexes are deposited onto the support materials, which are then suspended in the precipitating solution. Such a catalyst preparation method utilizes the fact that precipitation of the metal complexes onto the support surfaces requires a lower supersaturation than the formation of the new metal-containing phases directly in the solution phase. It is critical to maintain the supersaturation at a constant and moderate level. The control of the release rate of the precipitating agent, for example, by the controlled gradual addition of the precipitating agent is crucial to the homogeneous deposition of the metal precursor complexes. Deposition of metal-containing species from a precursor solution onto the support surfaces can be tuned through the fine control of the solution's $\mathrm{pH}$ value. The specific addition sequence of the various components, the droplet sizes, the appropriate turbulence of the solution, and the solution temperature, etc. affects the structure and chemistry of the final supported metal/alloy catalysts. The deposition-precipitation method works well for non-porous support materials or those materials that contain meso- and macropores. Such a method is excellent for individually separable particles of the support such as individually separable $\mathrm{ZnO}$ nanowires or other nanostructured support materials. We used the deposition-precipitation method and post-treatment manipulation to synthesize our ultrastable, epitaxially anchored PtZn nanoparticles supported on $\mathrm{ZnO}$ nanowires.

The BET (Brunauer-Emmett-Teller) surface area of the pristine $\mathrm{ZnO}$ nanowires was determined to be $17.6 \mathrm{~m}^{2} / \mathrm{g}$. After depositing the Pt species on the $\mathrm{ZnO}$ nanowires and the calcination treatment, the BET surface area of the $\mathrm{Pt} / \mathrm{ZnO} \mathrm{NW}$ catalyst was measured to be $16.3 \mathrm{~m}^{2} / \mathrm{g}$, slightly lower than that of the pristine $\mathrm{ZnO}$ nanowires. The nominal Pt loading was $1.0 \mathrm{wt}$. \% with a goal to disperse small Pt nanoparticles uniformly onto the ZnO nanowires. ICP-MS measurement of the actual Pt loading yielded a value of about $0.8 \mathrm{wt}$. \% of $\mathrm{Pt}$ in the final catalysts, slightly lower than the nominal loading level. Some Pt species were lost during the precipitation-deposition and probably the subsequent treatment processes. The calcined and reduced catalysts are labeled as $\mathrm{Pt} / \mathrm{ZnO} \mathrm{NW}-\mathrm{X}$ and $\mathrm{Pt} / \mathrm{ZnO}$ $\mathrm{NW}-\mathrm{HX}$, respectively, where " $\mathrm{X}$ " represents the calcination or reduction temperature. Unless otherwise stated the calcination and reduction time was 4 and $2 \mathrm{~h}$, respectively.

The representative SEM images of the pristine $\mathrm{ZnO}$ nanowires and the $\mathrm{Pt} / \mathrm{ZnO} \mathrm{NW}-\mathrm{H} 500$ catalyst (Figure 1a,b) show their typical morphology with lengths of tens of micrometers and diameters of tens of nanometers. The XRD patterns (Figure 1c) show that the pristine $\mathrm{ZnO}$ nanowires possess a wurtzite structure and that the structure of the $\mathrm{ZnO}$ nanowires did not change after being deposited with the Pt species, the calcination, and the reduction treatments. The XRD patterns do not display, however, any diffraction peaks that represent $\mathrm{Pt}$ or $\mathrm{PtZn}$ phases, presumably due to the high dispersion of the $\mathrm{Pt} / \mathrm{PtZn}$ species and/or the low Pt loading level.
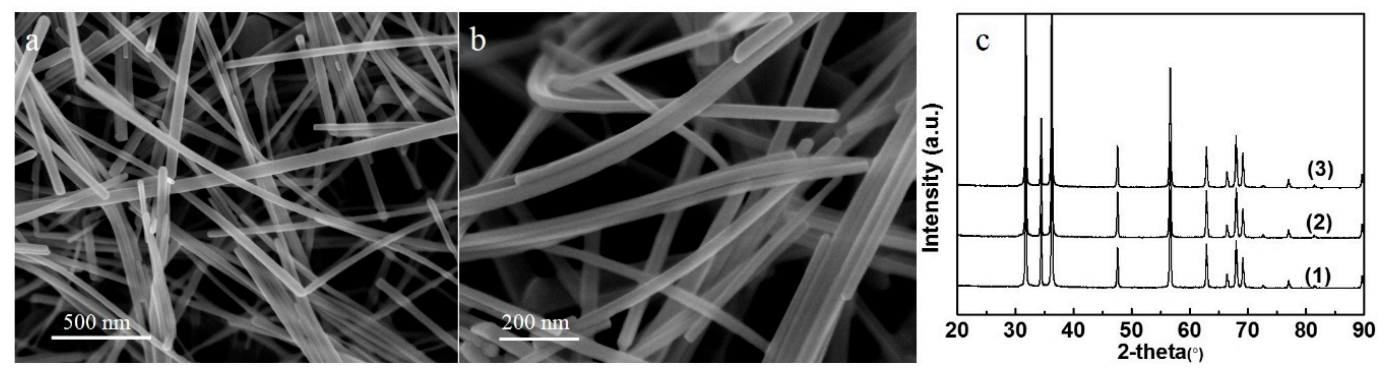

Figure 1. SEM images show (a) the typical morphology of the pristine $\mathrm{ZnO} N W$ s and (b) the $\mathrm{Pt} / \mathrm{ZnO}$ NW-H500 nanocatalyst. The XRD patterns (c) of (1) pristine ZnO NWs; (2) Pt/ZnO NW catalyst after reduction at $200{ }^{\circ} \mathrm{C}$; and (3) $\mathrm{Pt} / \mathrm{ZnO} \mathrm{NW}$ catalyst after reduction at $500{ }^{\circ} \mathrm{C}$. 
Figure 2 shows the representative high-angle annular dark-field scanning transmission electron microscopy (HAADF-STEM) images and the corresponding size distributions of the $\mathrm{Pt} / \mathrm{ZnO} \mathrm{NW}$ catalysts that had been calcined at $400^{\circ} \mathrm{C}$ and reduced at different temperatures. In HAADF-STEM images the signal intensity is determined by the sample thickness and the atomic number $Z$ of the probed elements of interest [32]. Therefore, columns of Pt atoms are brighter than the columns of $\mathrm{Zn}$ atoms provided that the imaged area is of similar thickness along the incident electron beam direction. Small Pt nanoparticles supported on $\mathrm{ZnO}$ NWs should give a high image contrast, as shown in Figure 2 . The Pt nanoparticles seem to be uniformly distributed along the surfaces of the $\mathrm{ZnO}$ NWs. The good dispersion is attributed to the strong interaction between the platinum precursor complexes and the $\mathrm{ZnO}$ NWs that possess a very high isoelectric point. Oxychlorinated species may have formed during the calcination step.

Figure 2 also shows that, after calcination at $400{ }^{\circ} \mathrm{C}$ and reduction at $200{ }^{\circ} \mathrm{C}$, the Pt species were highly dispersed on the $\mathrm{ZnO}$ NWs as nanoclusters $(\sim 1.0 \mathrm{~nm})$ with a narrow size distribution (Figure 2a,e). Raising the reduction temperature from $200{ }^{\circ} \mathrm{C}$ to $300^{\circ} \mathrm{C}$ slightly increased the size of the Pt nanoclusters. By increasing the reduction temperature to $500{ }^{\circ} \mathrm{C}$ and $650{ }^{\circ} \mathrm{C}$, the average sizes of the Pt nanoparticles increased to $1.9 \mathrm{~nm}$ and $2.8 \mathrm{~nm}$, respectively (Figure $2 \mathrm{c}, \mathrm{d}, \mathrm{g}, \mathrm{h}$ ) and the particle size distributions broadened as well, suggesting that high-temperature reduction promoted the sintering of Pt clusters.
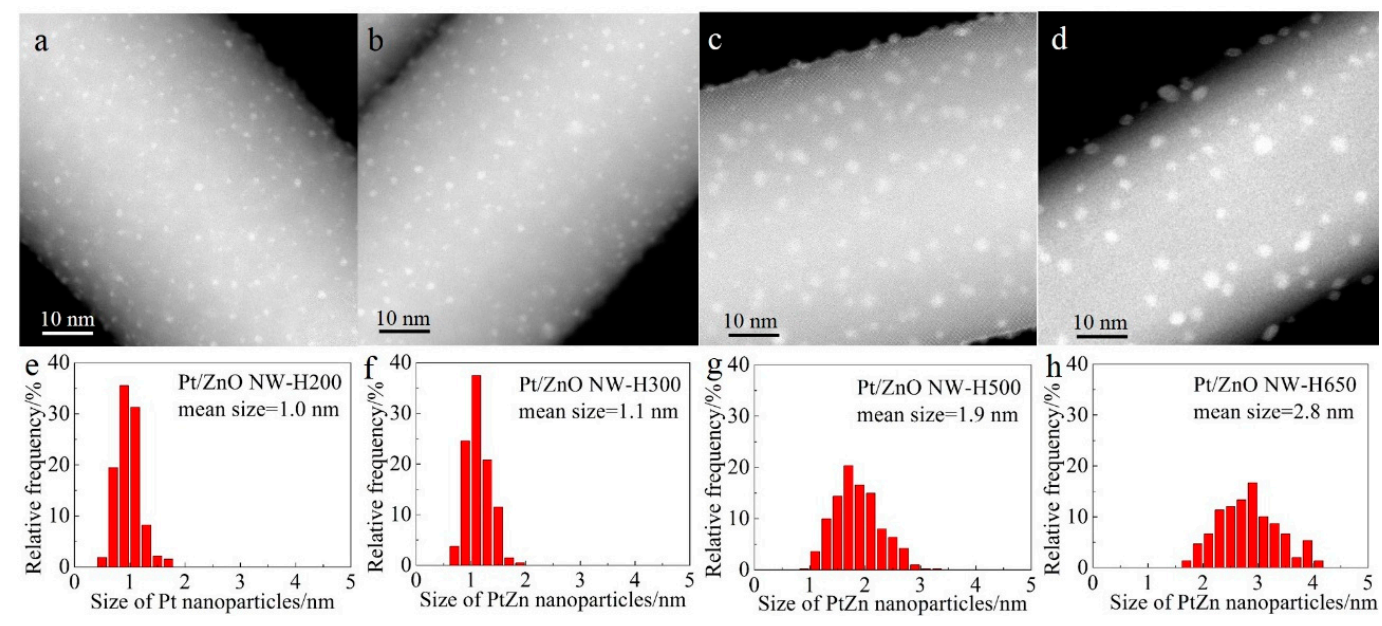

Figure 2. HAADF-STEM images of Pt/PtZn nanoparticles and their corresponding size distributions for Pt/ZnO NW catalysts reduced at various temperatures: (a) $200{ }^{\circ} \mathrm{C}$; (b) $300{ }^{\circ} \mathrm{C}$; (c) $500{ }^{\circ} \mathrm{C}$; and (d) $650{ }^{\circ} \mathrm{C}$. The corresponding particle size distributions are shown in (e-h) respectively.

Higher magnification HAADF-STEM images (Figure 3a,b) revealed that, after reduction at $200{ }^{\circ} \mathrm{C}$ and $300^{\circ} \mathrm{C}$, the $\mathrm{Pt} / \mathrm{PtZn}$ species randomly dispersed on the surfaces of the $\mathrm{ZnO} \mathrm{NWs}$, and some $\mathrm{PtZn}$ nanoparticles may have been formed with highly disordered or amorphous structure However, after being reduced at $500{ }^{\circ} \mathrm{C}$ (Figure 3c), the small clusters sintered to form nanoparticles that were oriented and aligned with respect to the $\mathrm{ZnO}\{10-10\}$ surfaces, resulting in a fixed crystallographic epitaxial relationship between the nanoparticles and the $\mathrm{ZnO}$ nanowires. Moreover, from Figure $3 \mathrm{c}$, we can clearly see that the small nanoparticles consist of dots with alternate bright and grey contrasts: the bright dots represent columns of $\mathrm{Pt}$ atoms, and the grey dots represent columns of $\mathrm{Zn}$ atoms along the incident electron beam direction. It has been reported that, during the $\mathrm{H}_{2}$ reduction at temperatures $>250{ }^{\circ} \mathrm{C}, \mathrm{Pt}$ nanoparticles interact with the $\mathrm{ZnO}$ support and that PtZn nanoalloys form $[27,29,30,33]$. Therefore, it is reasonable to conjecture that, after high temperature reduction, $\mathrm{PtZn}$ alloy nanoparticles were formed in our catalysts. 


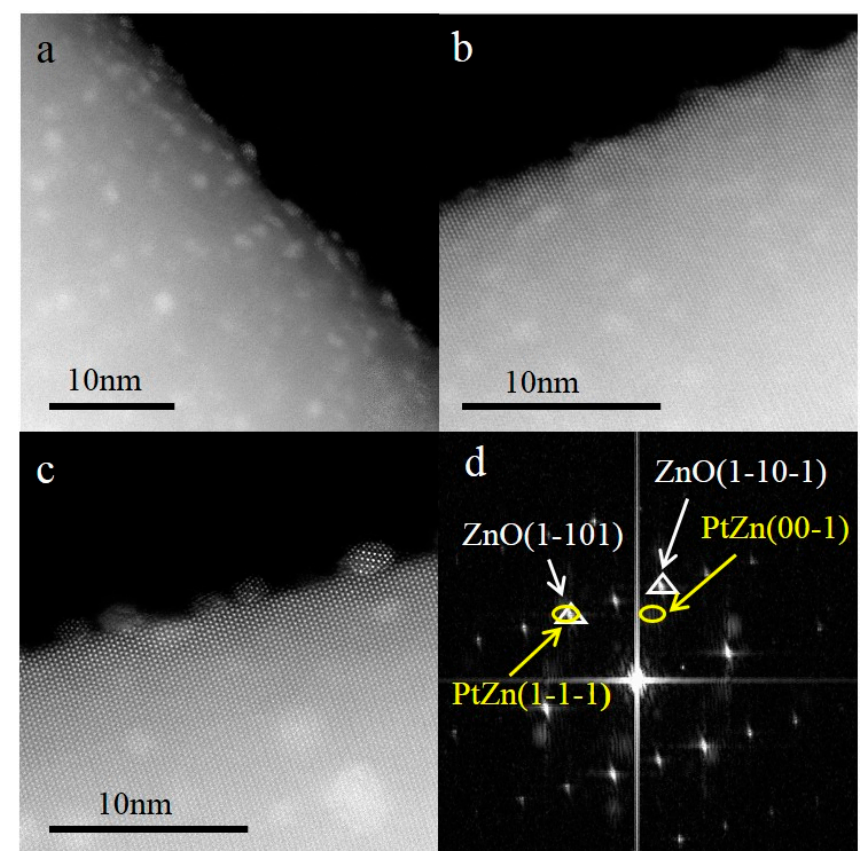

Figure 3. HAADF-STEM images of (a) Pt/ZnO NW-H200; (b) Pt/ZnO NW-H300; (c) Pt/ZnO NW-H500; and (d) digital diffractogram obtained from (c). The epitaxial growth of $\mathrm{PtZn}$ with respect to the $\mathrm{ZnO}$ NWs and columns of $\mathrm{Pt}$ and $\mathrm{Zn}$ atoms (bright and grey dots in (c)) are clearly revealed in (c). From the diffractogram (d), the epitaxial relationship between the PtZn nanoalloy and the $\mathrm{ZnO} \mathrm{NW}$ is determined: $\mathrm{ZnO}[11-20](1-101) / / \mathrm{PtZn}[110](1-1-1)$.

Detailed analysis of Figure $3 \mathrm{c}$ and other similar images can provide the specific alloy structure of the observed nanoparticles. The digital diffractogram (Figure 3d) obtained from Figure 3c displays spots of both the $\mathrm{ZnO}$ nanowire support (triangle) and the $\mathrm{PtZn}$ nanoparticles (ellipse). Analysis of the spot symmetry and the spacings (by using the spots of the $\mathrm{ZnO}$ as an internal reference) confirmed that the observed alloy particles are face-centered tetragonal PtZn $(a=b=4.03 \AA, c=3.51 \AA)$. Furthermore, from the digital diffractogram one can conclude that the PtZn nanoparticles grew with a fixed crystallographic relationship with respect to the $\mathrm{ZnO}$ nanowires. The PtZn $\{110\}$ planes were aligned along the $\mathrm{ZnO}\{11-20\}$ planes, while the $\mathrm{PtZn}\{1-1-1\}$ planes grew parallel with the $\mathrm{ZnO}$ $\{1-101\}$ planes. There is an angle of $\sim 5^{\circ}$ between the PtZn $\{00-1\}$ planes and the $\mathrm{ZnO}\{1-10-1\}$ planes. The epitaxial relationship between the $\mathrm{PtZn}$ nanoparticles and the $\mathrm{ZnO} N W s$ is designated as $\mathrm{ZnO}$ [11-20] (1-101)//PtZn [110] (1-1-1).

In order to study the atomic arrangement of the PtZn alloy nanoparticles and their relationship with respect to the $\mathrm{ZnO}$ NWs, the Pt/ZnO NW-H500 catalyst was further examined by HAADF-STEM with atomic scale resolution (Figure 4). Since the PtZn alloy nanoparticles grew epitaxially onto the $\mathrm{ZnO}$ NWs with a fixed crystallographic relationship when the ZnO NWs were oriented to the [11-20] zone axis, the associated PtZn alloy nanoparticles were automatically oriented to the $\{110\}$ zone axis. Such an epitaxial relationship makes it possible to thoroughly investigate the atomic structures of the interfacial regions between the PtZn alloy nanoparticles and the ZnO NWs. The lattice mismatches between the PtZn $\{1-1-1\}$ and the $\mathrm{ZnO}\{1-101\}$ planes, and the PtZn $\{00-1\}$ and the $\mathrm{ZnO}\{1-10-1\}$ planes, were about $10 \%$ and $30 \%$, respectively. Such large mismatches across heterointerfaces usually do not promote epitaxial growth. However, by introducing interfacial dislocations, epitaxial growth between heterostructures can proceed even with large mismatches, and the growth processes can be explained by invoking the domain matching epitaxy (DME) mechanism $[17,34,35]$. The presence of an interfacial dislocation at the interface between the small $\mathrm{PtZn}$ alloy nanoparticles and the ZnO NWs is clearly imaged in Figure 4a (indicated by the yellow arrow). Figure $4 \mathrm{~b}$ schematically illustrates 
the faceted PtZn nanoparticle and its crystallographic orientational relationship with respect to the $\mathrm{ZnO}$ NW. The ingrowth of the PtZn nanoparticles into the ZnO NWs can be understood in terms of $\mathrm{Pt}$-induced reduction of the $\mathrm{ZnO}$ at the contact interface and the subsequent inter-diffusion between $\mathrm{Zn}$ and Pt atoms to form PtZn alloy nanoparticles. The driving force is the lowering of the total system's energy by formation of $\mathrm{PtZn}$ alloy nanoparticles with an epitaxial relationship with the ZnO NW. The dominant $\{111\}$ faceting of the PtZn nanoparticles manifests the fact that the close-packed PtZn $\{111\}$ surfaces possessed the smallest surface energy. The specific shape of the PtZn nanoparticles may have also been affected by the interfacial strain and dislocations. Epitaxially anchored metal/alloy nanoparticles usually exhibit high structural stability during catalytic reactions [36].
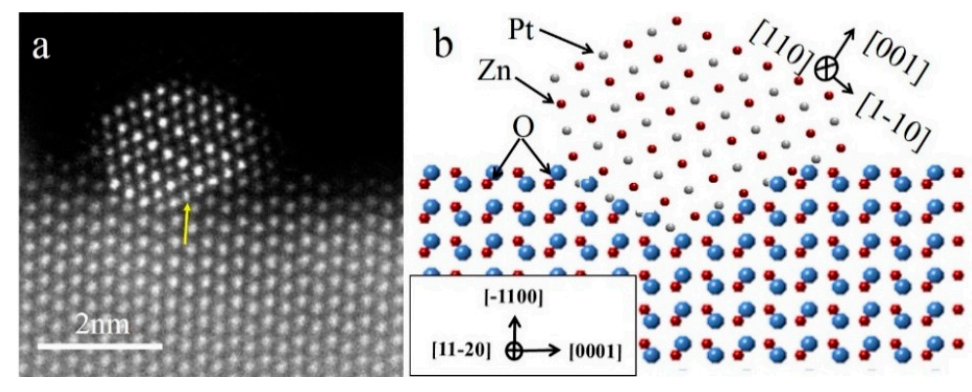

Figure 4. Atomic resolution HAADF-STEM image (a) of PtZn nanoparticle epitaxially anchored into $\mathrm{ZnO}$ NWs after being reduced at $500{ }^{\circ} \mathrm{C}$; (b) schematic diagram illustrating the partial embedment of the PtZn nanoparticle in the $\mathrm{ZnO}(10-10)$ nanoscale facet and the crystallographic orientation relationship between the PtZn nanofacets and the $\mathrm{ZnO}$ surfaces.

Figure 5 shows the atomic resolution HAADF-STEM images of a Pt/ZnO NW-H650 catalyst. The HAADF-STEM images show the oriented growth of the PtZn alloy nanoparticles (Figure 5a) and the interfacial structure between the PtZn and ZnO NW (Figure 5b). The bright-field phase contrast STEM image (Figure $5 \mathrm{c}$ ) clearly shows that the PtZn nanoparticles were covered by a thin layer of material, most likely $\mathrm{ZnO}_{x}$. The presence of the thin surface layer on the PtZn alloy nanoparticles suggests the SMSI (strong metal-support interaction) effect reported for the titania $\left(\mathrm{TiO}_{2}\right)$ supported group VIII system when reduced at temperatures higher than $500{ }^{\circ} \mathrm{C}$ under a $\mathrm{H}_{2}$ atmosphere [37,38]. It is interesting to note that, even after calcination at temperatures as high as $650^{\circ} \mathrm{C}$, the $\mathrm{PtZn}$ nanoparticles still maintained their epitaxial relationship with the $\mathrm{ZnO}$ NWs and did not grow significantly.

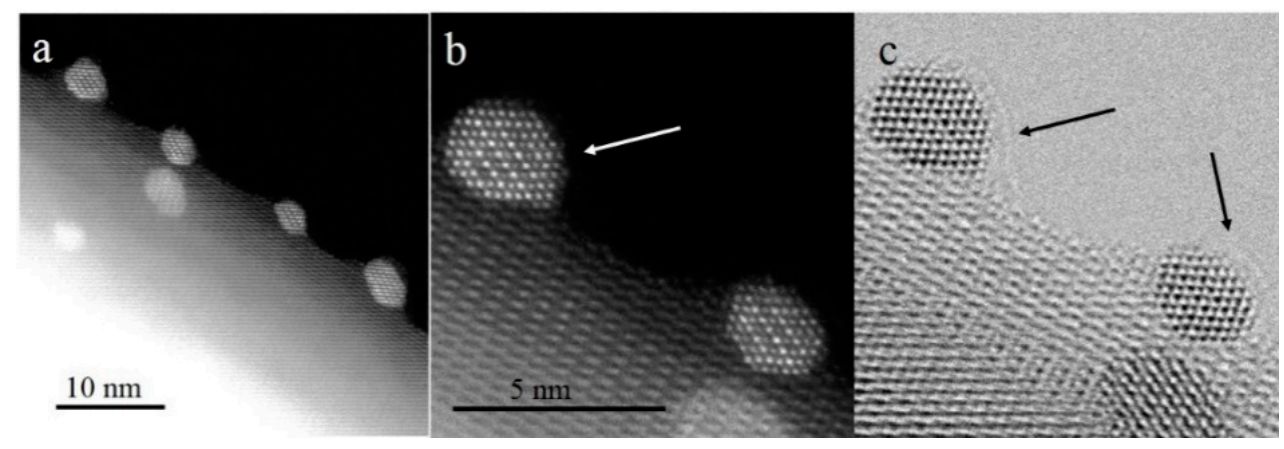

Figure 5. HAADF-STEM images (a,b) and bright-field STEM image (c) of a Pt/ZnO NW-H650 catalyst. Image (a) clearly demonstrates that, after being reduced at $650^{\circ} \mathrm{C}$, all the $\mathrm{PtZn}$ alloy nanoparticles were aligned in the same orientation with a similar shape and narrow size distribution. The surface atomic structure, the highly faceted shape, and the epitaxial growth of the $\mathrm{PtZn}$ nanoparticles are clearly shown in image (b). The bright-field STEM image (c) unambiguously shows that a thin layer of materials, most likely $\mathrm{ZnO}_{x}$, covered the PtZn alloy nanoparticles. Images $(\mathbf{b}, \mathbf{c})$ were obtained from the same region of the sample. 
The formation processes of the epitaxial growth of the PtZn alloy nanoparticles onto $\mathrm{ZnO}$ nanowires are illustrated in Scheme 1. Metal complexes are initially coated onto the $\mathrm{ZnO}$ nanowires. Then, calcination in air oxidatively removes the undesirable ligands that originate from the deposition of the metal precursor complexes onto the $\mathrm{ZnO}$ nanowires. When the $\mathrm{Pt} / \mathrm{ZnO}$ system is reduced in $\mathrm{H}_{2}$, the Pt-facilitated $\mathrm{H}_{2}$ dissociation reduces the $\mathrm{ZnO}$ to $\mathrm{ZnO}_{x}$ or $\mathrm{Zn}$; subsequently, the $\mathrm{Pt}$ and $\mathrm{Zn}$ interact to form PtZn bimetallic nanoparticles. During the PtZn nucleation and growth processes, the newly formed PtZn nanoparticles can grow with an epitaxial relationship with respect to the $\{10-10\}$ facets of the $\mathrm{ZnO}$ nanowires. The formation processes of the PtZn alloy nanoparticles depend on the reduction temperature and time. At reduction temperatures at $400{ }^{\circ} \mathrm{C}$ or above, $\mathrm{PtZn}$ alloy nanoparticles can be easily formed and grow epitaxially. At very high reduction temperatures, $\mathrm{ZnO}$ may further interact with the PtZn alloy nanoparticles resulting in a thin layer of $\mathrm{ZnO}_{x}$ species covering the PtZn surfaces. Our goal is to produce the smallest PtZn bimetallic alloy nanoparticles that are epitaxially anchored into the $\{10-10\}$ nanoscale facets of the $\mathrm{ZnO}$ nanowires.

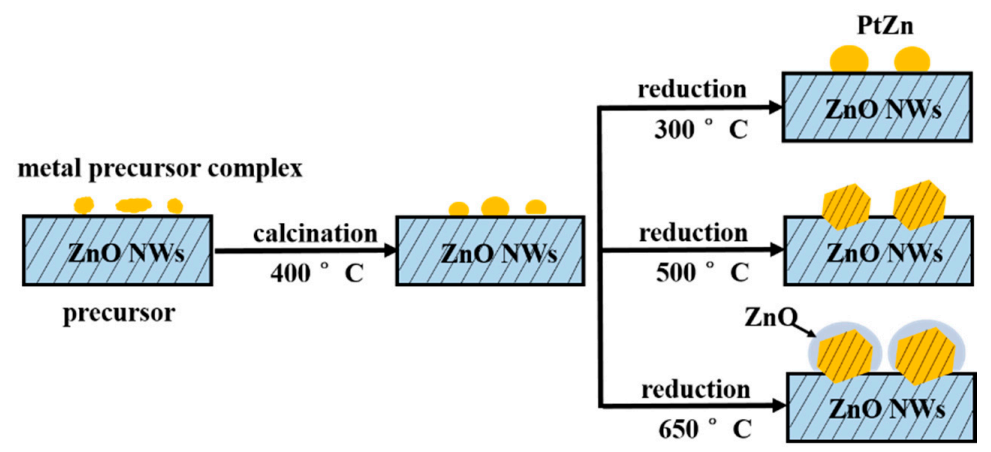

Scheme 1. Schematic diagram illustrates the structural evolution and the formation processes of PtZn alloy nanoparticles, their epitaxial growth on $\mathrm{ZnO}$ NWs, and the SMSI at very high reduction temperatures.

We used the WGS reaction as a probe to evaluate the catalytic performance and the stability of the epitaxial PtZn alloy nanoparticles. We choose this reaction because of its importance for energy applications and because many catalyst systems are not stable during the WGS reaction. Figure 6a displays the $\mathrm{CO}$ conversion profiles as a function of reaction temperature over the $\mathrm{Pt} / \mathrm{ZnO}-\mathrm{NW}-\mathrm{H} 200$, $\mathrm{Pt} / \mathrm{ZnO}-\mathrm{NW}-\mathrm{H} 300$, and Pt/ZnO-NW-H500 catalysts, respectively. The observed higher activity of the Pt/ZnO NW-H300 (compared to that of the Pt/ZnO NW-H200) is interesting since the sizes of the nanoclusters in the $\mathrm{Pt} / \mathrm{ZnO} \mathrm{NW}-\mathrm{H} 300$ catalyst are similar to, or even slightly larger than, the nanoclusters in the $\mathrm{Pt} / \mathrm{ZnO}$ NW-H200 catalyst. The activity differences must have originated from the effects of the $\mathrm{H}_{2}$ reduction treatment at different temperatures. Considering that $\mathrm{PtZn}$ alloy can form during $\mathrm{H}_{2}$ reduction at temperatures higher than $250{ }^{\circ} \mathrm{C}[27,29,30,33]$, we propose that the presence of the PtZn alloy nanoparticles in the Pt/ZnO NW-H300 catalyst may have improved the WGS activity. Detailed examinations revealed that there were no detectable $\mathrm{PtZn}$ alloy nanoparticles in the $\mathrm{Pt} / \mathrm{ZnO}$ NW-H200 catalyst.

The initial low activity of the PtZn/ZnO NW-H500 (compared to that of the Pt/ZnO NW-H200 and $\mathrm{Pt} / \mathrm{ZnO} \mathrm{NW}-\mathrm{H} 300$ catalysts) can be attributed to the larger sizes of the PtZn alloy nanoparticles. The activity of the $\mathrm{Pt} / \mathrm{ZnO} \mathrm{NW}-\mathrm{H} 650$ was much lower than that of the other catalysts, presumably caused by (1) the encapsulation of the PtZn alloy nanoparticles by the $\mathrm{ZnO}_{x} / \mathrm{Zn}$ surface coating layers and (2) the significant growth of the PtZn alloy nanoparticles during the high temperature reduction treatment. We have also investigated the WGS reaction on Pt nanoparticles supported on $\mathrm{ZnO}$ powders (Figure 6b). The activity of the $\mathrm{ZnO}$ powder-supported PtZn catalyst was higher than that of the $\mathrm{Pt} / \mathrm{ZnO} \mathrm{NW}$ catalysts. PtZn alloy nanoparticles were formed as well and some, but not all, alloy nanoparticles grew epitaxially onto the $\mathrm{ZnO}$ powders. The observed higher activity may be related to 
the presence of $\mathrm{ZnO}$ polar surfaces (e.g., $\mathrm{ZnO}\{0001\}$ facets) that may interact with the Pt differently. However, the $\mathrm{ZnO}$ powders are not stable at high calcination or reduction temperatures [36].
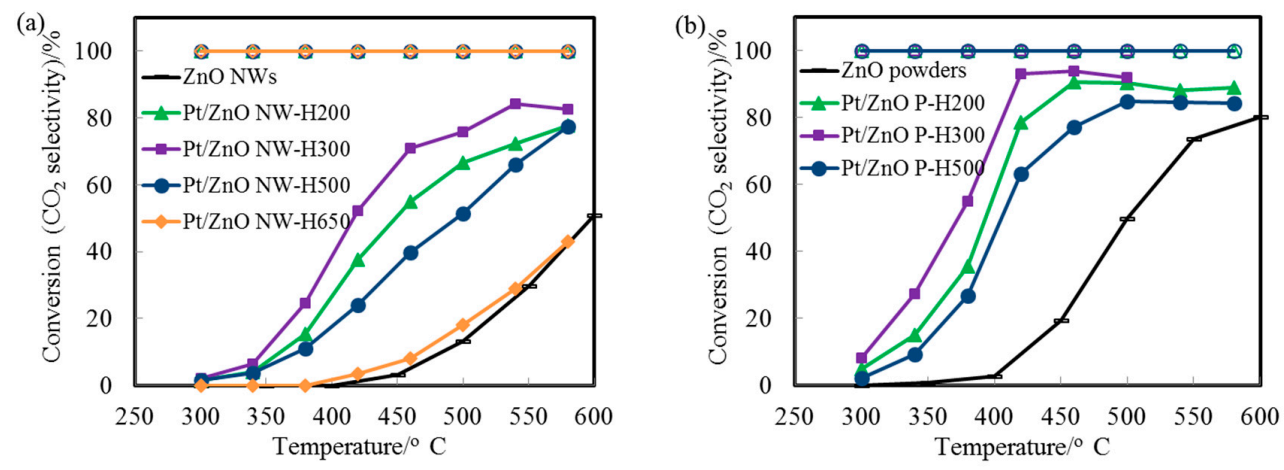

Figure 6. CO Conversion for WGS reaction over (a) the $\mathrm{Pt} / \mathrm{ZnO} \mathrm{NW}$ and (b) the $\mathrm{Pt} / \mathrm{ZnO}$ powder catalysts after different degrees of reduction treatment. The $\mathrm{CO}_{2}$ selectivity was $100 \%$ for all the catalysts (open symbols) tested.

Figure 7a shows the $\mathrm{CO}$ conversion at $500{ }^{\circ} \mathrm{C}$ with time on stream for $\mathrm{Pt} / \mathrm{ZnO} \mathrm{NW}-\mathrm{H} 200, \mathrm{Pt} / \mathrm{ZnO}$ NW-H300, Pt/ZnO NW-H500, and Pt/ZnO NW-H650 catalysts, respectively. The CO conversion of the Pt/ZnO NW-H200 and Pt/ZnO NW-H300 catalysts decreased about 20\% during the 30-h test. Such deactivation is most likely caused by the sintering of the small Pt or PtZn nanoclusters during the high temperature WGS reaction. To determine the degree of particle sintering, we measured the $\mathrm{Pt} / \mathrm{ZnO}$ NW-H300 sample after the 30-h test. Figure 8 shows the HAADF-STEM images and the corresponding particle size distributions of the used catalyst. After the stability test, the mean particle size of the $\mathrm{Pt} / \mathrm{ZnO}$ NW-H300 catalyst increased from approximately $1.1 \mathrm{~nm}$ to about $2.3 \mathrm{~nm}$ in diameter. On the other hand, the particle sizes in the Pt/ZnO NW-H500 catalyst did not change much at all and showed much better stability. The epitaxial growth stabilized the PtZn alloy nanoparticles both during the catalyst treatments and catalytic reactions.
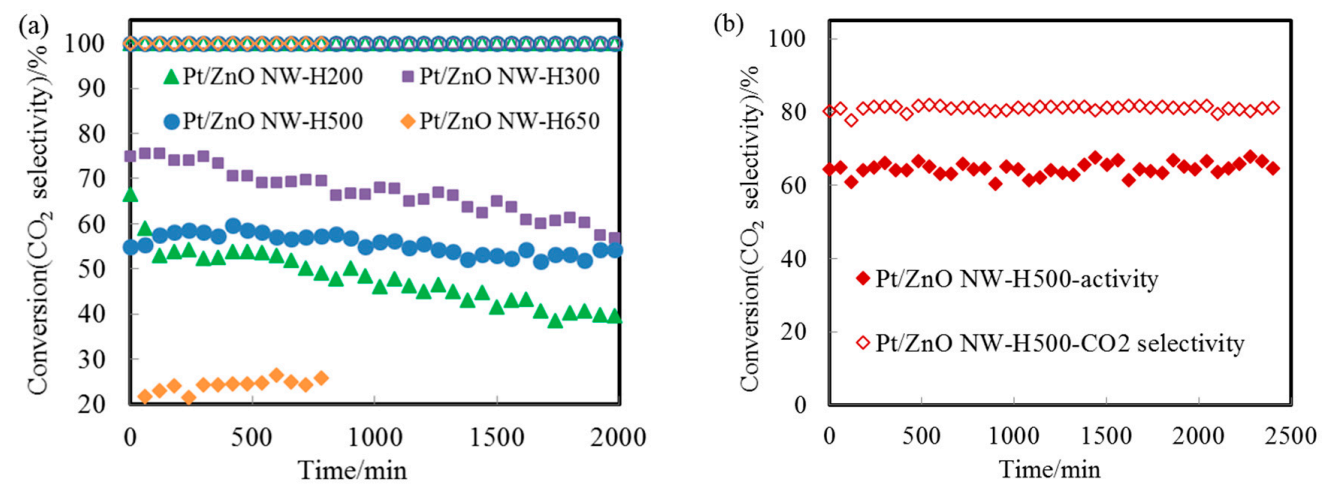

Figure 7. (a) Stability test over the $\mathrm{Pt} / \mathrm{ZnO} \mathrm{NW}-\mathrm{H} 200$ (green triangle), $\mathrm{Pt} / \mathrm{ZnO} \mathrm{NW}-\mathrm{H} 300$ (purple square), $\mathrm{Pt} / \mathrm{ZnO}$ NW-H500 (blue circle), and Pt/ZnO NW-H650 (orange diamond) for the WGS reaction at $500{ }^{\circ} \mathrm{C}$. The $\mathrm{CO}_{2}$ selectivity was $100 \%$ for all the catalysts (open symbols); (b) the stability test over the $\mathrm{Pt} / \mathrm{ZnO} \mathrm{NW}-\mathrm{H} 500$ catalyst for the methanol steam reforming reaction. The filled and open symbols represent the conversion and $\mathrm{CO}_{2}$ selectivity, respectively.

The catalytic performance of alloy nanoparticles depends strongly on the bonding strength between the alloying elements [31]. It has been reported that bonding between $\mathrm{Pt}$ and $\mathrm{Zn}$ produces a large depletion in the density of $\mathrm{Pt}(5 \mathrm{~d})$ states around the Fermi level, with a shift in the centroid of the Pt $5 \mathrm{~d}$ band and $4 \mathrm{f}$ core levels toward higher binding energy [39]. The formation of the PtZn 
clusters suggests that bimetallic bonding destabilizes the $\mathrm{Pt}(5 \mathrm{~d})$ orbitals as well the $\mathrm{Zn}(3 \mathrm{~d})$ orbitals. The formation of strong Pt-Zn bonds modifies the adsorption property of Pt toward CO molecules. It has been proposed that the bonding between $\mathrm{Pt}$ and $\mathrm{Zn}$ weakens the bonding between the $\mathrm{Pt}$ atoms and the $\mathrm{CO}$ molecules [39]. Such alloying induced modification of the chemisorption of $\mathrm{CO}$ molecules may strongly depend on the faceting and surface composition of the PtZn alloy nanoparticles. The stability of the PtZn alloy nanoparticles should therefore depend on the specific catalytic reactions and the reaction temperature.
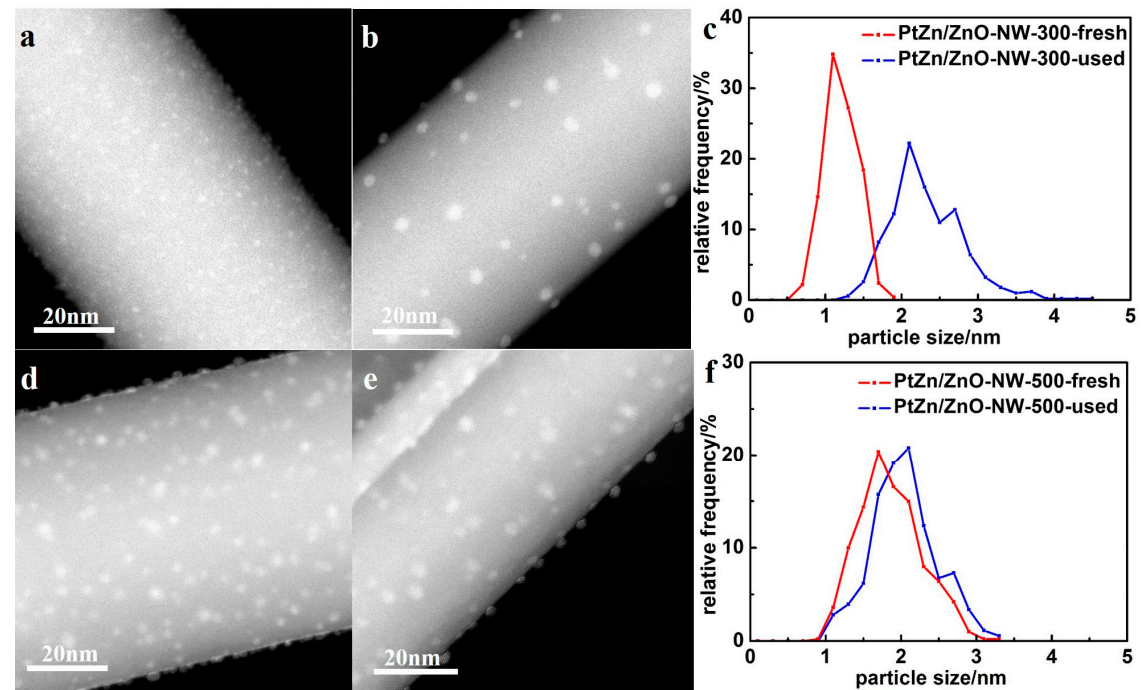

Figure 8. HAADF-STEM images of $\mathrm{Pt} / \mathrm{ZnO}$ NW-H300 and $\mathrm{Pt} / \mathrm{ZnO} \mathrm{NW}-\mathrm{H} 500$ catalysts before (a,d) and after $(\mathbf{b}, \mathbf{e})$ a $30-\mathrm{h}$ stability test and $(\mathbf{c}, \mathbf{f})$ their corresponding particle size distributions.

The atomic resolution HAADF-STEM images (Figure 9) clearly show that the epitaxial relationship between the PtZn nanoparticles and the $\mathrm{ZnO}$ nanowires did not change at all after the 30-h stability test, further suggesting the excellent stability of the epitaxially anchored PtZn nanoparticles. Furthermore, the nanoscale facets of the PtZn alloy nanoparticles, the interfacial structure between the PtZn alloy nanoparticles and the $\mathrm{ZnO}$ nanowires, and the shapes of the PtZn nanoalloys did not change at all during the 30-h test.

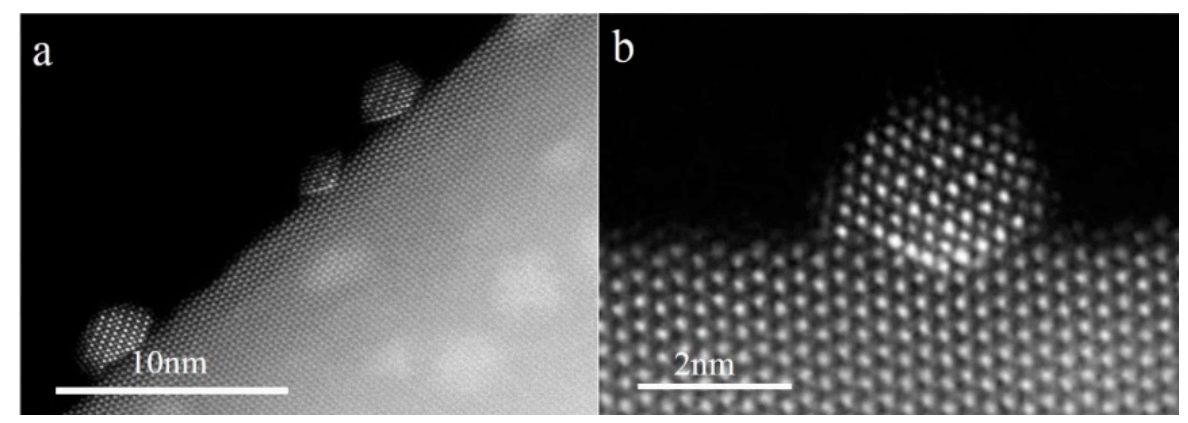

Figure 9. HAADF-STEM images of a Pt/ZnO NW-H500 catalyst after a 30-h test for WGS reaction. The alloy nature, the shape, and the interracial structure between the PtZn nanoparticles and the $\mathrm{ZnO}$ nanowires did not show any observable change after the 30-h test.

We further tested the Pt/ZnO NW-H500 catalyst for methanol steam reforming (MSR) at $400{ }^{\circ} \mathrm{C}$. As shown in Figure 7b, the epitaxially anchored PtZn nanoparticles on ZnO NWs demonstrated persistent resistance to sintering and maintained excellent durability for the MSR reaction as well. 


\section{Materials and Methods}

\subsection{Catalyst Preparation}

$\mathrm{ZnO}$ nanowires (NWs) were fabricated by a modified vapor transport and condensation method [40]. Firstly, a uniform mixture of $\mathrm{ZnO}$ and $\mathrm{C}$ was obtained by mixing $\mathrm{ZnO}$ powders (99\%, Sigma-Aldrich, Tempe, AZ, USA) and carbon black (Cabot Corp, Alpharetta, GA, USA) in the weight ratio of 1:1 with the addition of deionized water. Then, the mixture was dried in the oven at $200{ }^{\circ} \mathrm{C}$ for $10 \mathrm{~h}$ to remove water. For the synthesis of $\mathrm{ZnO}$ nanowires, about $3 \mathrm{~g}$ of the mixture was ground into powders and placed into a high-temperature furnace. Under 10 vol. $\% \mathrm{O}_{2} / \mathrm{N}_{2}$ flowing gas, the mixture was heated to $>900{ }^{\circ} \mathrm{C}$, and the ultrapure $\mathrm{ZnO}$ NWs were collected downstream.

The ZnO NW supported Pt nanocatalysts were prepared by a modified deposition-precipitation method. The $\mathrm{H}_{2} \mathrm{PtCl}_{6} \cdot 6 \mathrm{H}_{2} \mathrm{O}$ solution was added dropwise into the suspension containing ZnO NWs under constant stirring. Sodium carbonate $\left(\mathrm{Na}_{2} \mathrm{CO}_{3}\right)$ solution was added simultaneously to adjust the $\mathrm{pH}$ value at 7.0 . After being stirred and aged for $2 \mathrm{~h}$ respectively, the suspension was filtered and washed with deionized water for several times. The resultant solid was dried at $60{ }^{\circ} \mathrm{C}$ for $12 \mathrm{~h}$ and calcined at $400{ }^{\circ} \mathrm{C}$ for $4 \mathrm{~h}$ in air. The catalyst was reduced in situ at different temperatures for $2 \mathrm{~h}$ in 10 vol. \% $\mathrm{H}_{2} / \mathrm{He}$ prior to catalytic reaction. The supported $\mathrm{Pt}$ catalysts reduced at different temperature were denoted as $\mathrm{Pt} / \mathrm{ZnO} \mathrm{NW}-\mathrm{HX}$, where $\mathrm{X}$ represents the reduction temperature.

\subsection{Characterization Techniques}

The actual metal loadings of the catalysts were measured by inductively coupled plasma-mass spectroscopy (ICP-MS) on an Agilent 7500ce instrument (Agilent, Santa Clara, CA, USA). $\mathrm{N}_{2}$ adsorption measurements were performed on a Micromeritics ASAP 2020 instrument (Micromeritics, Shanghai, China) at $-196^{\circ} \mathrm{C}$, and the surface area of the support was obtained via the Brunauer-Emmett-Teller (BET) method.

The powder X-ray Diffraction (XRD) measurements were carried out on a PANalytical X'pert PRO X-ray (PANalytical, Shanghai, China) diffractometer using Cu K $\alpha$ radiation (1.5405 ̊) operating at $40 \mathrm{kV}$ and $40 \mathrm{~mA}$. Data recorded at a step size of $0.013^{\circ}$ under continuous scan mode.

The morphology of the $\mathrm{ZnO}$ NWs was characterized by a field emission scanning electron microscope (Hitachi, S-4800, Hitachi, Tokyo, Japan). HAADF images of the ZnO nanowires and the catalysts were obtained on a JEOL ARM-200F (JEOL, Huntington Beach, CA, USA) aberration-corrected STEM (AC-STEM) operated at $200 \mathrm{kV}$ with a nominal spatial resolution of $0.08 \mathrm{~nm}$ in the STEM mode. Samples were prepared through a typical procedure by depositing dispersed catalysts in ethanol and were then transferred onto copper TEM grids.

\subsection{Measurement of Catalytic Activity}

The activity tests were conducted in a fixed-bed reactor. The catalyst samples were placed in a quartz tube (ID $=4 \mathrm{~mm}$ ) with the two ends of the catalyst bed filled with quartz wool. For WGS reaction, the stability test were performed at $500{ }^{\circ} \mathrm{C}$. Typically, a $0.05-\mathrm{g}$ catalyst was used, and the reaction feed, composed of 2 vol. \% CO/10 vol. \% $\mathrm{H}_{2} \mathrm{O}$ and balance $\mathrm{He}$, was passed through the catalyst bed at desired temperatures with a total flow rate of about $40 \mathrm{~mL} / \mathrm{min}$. The gas hourly space velocity (GHSV) was $48,000 \mathrm{~mL} / \mathrm{h} \mathrm{g}_{\text {cat }}$. The effluent gas compositions were on line analyzed by a gas chromatograph (HP 7890, HP, Palo Alto, CA, USA) equipped with a HayeSep DB column. The CO conversion was defined as $\mathrm{C}_{\mathrm{CO}}=\left[(\mathrm{CO})_{\text {in }}-(\mathrm{CO})_{\text {out }}\right] /(\mathrm{CO})_{\text {in }} \times 100 \%$, where $(\mathrm{CO})_{\text {in }}$ and $(\mathrm{CO})_{\text {out }}$ were the inlet and outlet molar weight of $\mathrm{CO}$. The selectivity to $\mathrm{CO}_{2}$ was defined as $\mathrm{S}_{\mathrm{CO}_{2}}=\mathrm{C}_{\mathrm{CO}_{2}} /\left(\mathrm{C}_{\mathrm{CO}_{2}}+\mathrm{C}_{\mathrm{CH}_{4}}\right) \times 100 \%$, where $\mathrm{C}_{\mathrm{CO}_{2}}$ and $\mathrm{C}_{\mathrm{CH}_{4}}$ were the molar weight of $\mathrm{CO}_{2}$ and $\mathrm{CH}_{4}$ in the product. No other carbon-containing products were detected.

For the MSR reaction, the stability test were performed at $400{ }^{\circ} \mathrm{C}$. A $0.05-\mathrm{g}$ catalyst was used, and the reaction feed, composed of methanol/water (mole ratio 2/3, $0.6 \mathrm{~mL} / \mathrm{h}$ in liquid), and He (37 $\mathrm{mL} / \mathrm{min}$ ) was passed through the catalyst bed at desired temperatures. The gas hourly space 
velocity (GHSV) was $54,000 \mathrm{~mL} / \mathrm{h}$ g cat. The reaction feed was preheated to $165{ }^{\circ} \mathrm{C}$ to vaporize methanol/water mixture. The effluent gas compositions were online analyzed by a gas chromatograph (HP 7890) equipped with a HayeSep DB column (Agilent, Santa Clara, CA, USA). Quantitative analysis of $\mathrm{CO}, \mathrm{CO}_{2}$, and methanol was realized by calibrating with standard samples. The methanol conversion was calculated based on the difference between inlet and outlet concentrations. The selectivity of $\mathrm{CO}_{2}$ formation was determined as moles of $\mathrm{CO}_{2}$ per mole of $\mathrm{CO}_{2}+\mathrm{CO}$ in the products.

\section{Conclusions}

In summary, this work presents a novel approach to developing ultrastable supported bimetallic catalysts via epitaxial anchoring. PtZn alloy nanoparticles form when the reduction temperatures are above $300{ }^{\circ} \mathrm{C}$. When the molecular precursor species were uniformly coated onto the $\mathrm{ZnO}$ nanowires, which primarily consists of the low-energy and stable $\{10-10\}$ nanoscale facets, the nucleation and growth of epitaxial PtZn nanoalloys will occur. These PtZn alloy nanoparticles exhibited very good durability under high-temperature WGS and MRS reactions. The observed stability of the PtZn nanoalloys can be ascribed to their epitaxial growth as well as the partial embedding of the PtZn nanoparticles into the highly faceted $\mathrm{ZnO}$ nanowires. The method reported in this paper for designing and synthesizing ultrastable metal/alloy nanoparticles is general and can be extended to synthesizing many other kinds of supported metal/alloy catalysts.

Acknowledgments: This work was funded by the start-up fund of the College of Liberal Arts and Sciences of Arizona State University, the Chinese Scholarship Council (CSC), and the US National Science Foundation under CHE-1465057. The authors acknowledge the use of facilities in the John M. Cowley Center for High Resolution Electron Microscopy at Arizona State University.

Author Contributions: J.Y.L. and J.X.L. conceived and designed the experiments; J.X.L. performed the synthesis and catalytic test experiments; J.Y.L. performed the high resolution STEM characterization; J.Y.L., B.T.Q., and J.X.L. analyzed the data; J.Y.L., Y.D.H., and Y.A.S. contributed reagents/materials/analysis tools; J.X.L. and J.Y.L. wrote the paper.

Conflicts of Interest: The authors declare no conflict of interest.

\section{References}

1. Sankar, M.; Dimitratos, N.; Miedziak, P.J.; Well, P.P.; Kiely, C.J.; Hutchinqs, G.J. Designing bimetallic catalysts for a green and sustainable future. Chem. Soc. Rev. 2012, 41, 8099-8139. [CrossRef] [PubMed]

2. Toshima, N.; Yonezawa, T. Bimetallic nanoparticles-novel materials for chemical and physical applications. New J. Chem. 1998, 22, 1179-1201. [CrossRef]

3. Sun, J.; Bao, X. Textural Manipulation of Mesoporous Materials for Hosting of Metallic Nanocatalysts. Chem. Eur. J. 2008, 14, 7478-7488. [CrossRef] [PubMed]

4. Li, D.; Nakagawa, Y.; Tomishige, K. Methane reforming to synthesis gas over Ni catalysts modified with noble metals. Appl. Catal. A Gen. 2011, 408,1-24. [CrossRef]

5. Diao, W.; Tengco, J.M.M.; Regalbuto, J.R.; Monnier, J.R. Preparation and Characterization of Pt-Ru Bimetallic Catalysts Synthesized by Electroless Deposition Methods. ACS Catal. 2015, 5, 5123-5134. [CrossRef]

6. Zhang, Y.; Diao, W.; Williams, C.T.; Monnier, J.R. Selective hydrogenation of acetylene in excess ethylene using $\mathrm{Ag}$ - and $\mathrm{Au}-\mathrm{Pd} / \mathrm{SiO}_{2}$ bimetallic catalysts prepared by electroless deposition. Appl. Catal. A Gen. 2014, 469, 419-426. [CrossRef]

7. Rebelli, J.; Detwiler, M.; Ma, S.; Williams, C.T.; Monnier, J.R. Synthesis and characterization of $\mathrm{Au}-\mathrm{Pd} / \mathrm{SiO} 2$ bimetallic catalysts prepared by electroless deposition. J. Catal. 2010, 270, 224-233. [CrossRef]

8. Cho, H.R.; Regalbuto, J.R. The rational synthesis of Pt-Pd bimetallic catalysts by electrostatic adsorption. Catal. Today 2015, 246, 143-153. [CrossRef]

9. Feltes, T.E.; Espinosa-Alonso, L.; de Smit, E.; D'Souza, L.; Meyer, R.J.; Weckhuysen, B.M.; Regalbuto, J.R. Selective adsorption of manganese onto cobalt for optimized $\mathrm{Mn} / \mathrm{Co} / \mathrm{TiO}_{2}$ Fischer-Tropsch catalysts. J. Catal. 2010, 270, 95-102. [CrossRef] 
10. Job, N.; Lambert, S.; Chatenet, M.; Gommes, C.J.; Maillard, F.; Berthon-Fabry, S.; Regalbuto, J.R.; Pirard, J.P. Preparation of highly loaded Pt/carbon xerogel catalysts for Proton Exchange Membrane fuel cells by the Strong Electrostatic Adsorption method. Catal. Today 2010, 150, 119-127. [CrossRef]

11. Lambert, S.; Job, N.; D'Souza, L.; Pereira, M.F.R.; Pirard, R.; Heinrichs, B.; Figueiredo, J.L.; Pirard, J.P.; Regalbuto, J.R. Synthesis of very highly dispersed platinum catalysts supported on carbon xerogels by the strong electrostatic adsorption method. J. Catal. 2009, 261, 23-33. [CrossRef]

12. Jiao, L.; Regalbuto, J.R. The synthesis of highly dispersed noble and base metals on silica via strong electrostatic adsorption: I. Amorphous silica. J. Catal. 2008, 260, 329-341. [CrossRef]

13. Harris, P.J.F. The sintering of platinum particles in an alumina-supported catalyst: Further transmission electron microscopy studies. J. Catal. 1986, 97, 527-542. [CrossRef]

14. Fiedorow, R.M.J.; Chahar, B.S.; Wanke, S.E. The sintering of supported metal catalysts: II. Comparison of sintering rates of supported Pt, Ir, and Rh catalysts in hydrogen and oxygen. J. Catal. 1978, 51, 193-202.

15. Enterkin, J.A.; Poeppelmeier, K.R.; Marks, L.D. Oriented catalytic platinum nanoparticles on high surface area strontium titanate nanocuboids. Nano Lett. 2011, 11, 993-997. [CrossRef] [PubMed]

16. Pashley, D.W. The study of epitaxy in thin surface films. Adv. Phys. 1956, 5, 173-240. [CrossRef]

17. Chugh, A.; Ramachandran, S.; Tiwari, A.; Narayan, J. Epitaxial ZnO/Pt layered structures and ZnO-Pt nanodot composites on sapphire (0001). J. Electron. Mater. 2006, 35, 840-845. [CrossRef]

18. Gatel, C.; Baules, P.; Snoeck, E. Morphology of Pt islands grown on MgO(001). J. Cryst. Growth 2003, 252, 424-432. [CrossRef]

19. Gatel, C.; Snoeck, E. Comparative study of Pt, Au and Ag growth on $\mathrm{Fe}_{3} \mathrm{O}_{4}(001)$ surface. Surf. Sci. 2006, 600, 2650-2662. [CrossRef]

20. Gatel, C.; Snoeck, E. Epitaxial growth of Au and Pt on $\mathrm{Fe}_{3} \mathrm{O}_{4}(111)$ surface. Surf. Sci. 2007, 601, 1031-1039. [CrossRef]

21. Chu, S.; Ren, J.; Yan, D.; Huang, J.; Liu, J. Noble metal nanodisks epitaxially formed on ZnO nanorods and their effect on photoluminescence. Appl. Phys. Lett. 2012, 101. [CrossRef]

22. Behafarid, F.; Cuenya, B.R. Nanoepitaxy using micellar nanoparticles. Nano Lett. 2011, 11, 5290-5296. [CrossRef] [PubMed]

23. Capper, P.; Irvine, S.; Joyce, T. Epitaxial Crystal Growth: Methods and Materials. In Handbook of Electronic and Photonic Materials; Kasap, S., Capper, P., Eds.; Springer: New York, NY, USA, 2007; pp. 271-301.

24. Huang, X.; Zeng, Z.; Bao, S.; Wang, M.; Qi, X.; Fan, Z.; Zhang, H. Solution-phase epitaxial growth of noble metal nanostructures on dispersible single-layer molybdenum disulfide nanosheets. Nat. Commun. 2013, 4. [CrossRef] [PubMed]

25. Miura, A.; Wang, H.; Leonard, B.M.; Abruña, H.D.; DiSalvo, F.J. Synthesis of Intermetallic PtZn Nanoparticles by Reaction of Pt Nanoparticles with Zn Vapor and Their Application as Fuel Cell Catalysts. Chem. Mat. 2009, 21, 2661-2667. [CrossRef]

26. Sode, A.; Musgrove, A.; Bizzotto, D. Stability of PtZn Nanoparticles Supported on Carbon in Acidic Electrochemical Environments. J. Phys. Chem. C 2010, 114, 546-553. [CrossRef]

27. Ammari, F. An emergent catalytic material: $\mathrm{Pt} / \mathrm{ZnO}$ catalyst for selective hydrogenation of crotonaldehyde. J. Catal. 2004, 221, 32-42. [CrossRef]

28. Silvestre-Albero, J. Improved Metal-Support Interaction in $\mathrm{Pt} / \mathrm{CeO}_{2} / \mathrm{SiO}_{2}$ Catalysts after Zinc Addition. J. Catal. 2002, 210, 127-136. [CrossRef]

29. Wang, D.; Ammari, F.; Touroude, R.; Su, D.S.; Schlögl, R. Promotion effect in Pt-ZnO catalysts for selective hydrogenation of crotonaldehyde to crotyl alcohol: A structural investigation. Catal. Today 2009, 147, 224-230. [CrossRef]

30. Consonni, M.; Jokic, D.; Yu Murzin, D.; Touroude, R. High Performances of Pt/ZnO Catalysts in Selective Hydrogenation of Crotonaldehyde. J. Catal. 1999, 188, 165-175. [CrossRef]

31. Long, N.V.; Yang, Y.; Minh Thi, C.; Van Minh, N.; Cao, Y.; Nogami, M. The development of mixture, alloy, and core-shell nanocatalysts with nanomaterial supports for energy conversion in low-temperature fuel cells. Nano Energy 2013, 2, 636-676. [CrossRef]

32. Crewe, A.V.; Wall, J.; Langmore, J. Visibility of Single Atoms. Science 1970, 168, 1338-1340. [CrossRef] [PubMed] 
33. Boccuzzi, F.; Chiorino, A.; Ghiotti, G.; Pinna, F.; Strukul, G.; Tessari, R. Pt/ZnO catalysts: Spectroscopic and catalytic evidences of a ligand effect as a consequence of PtZn alloying. J. Catal. 1990, 126, 381-387. [CrossRef]

34. Narayan, J.; Larson, B.C. Domain epitaxy: A unified paradigm for thin film growth. J. Appl. Phys. 2003, 93. [CrossRef]

35. Ramachandran, S.; Chugh, A.; Tiwari, A.; Narayan, J. Growth of highly conducting epitaxial ZnO-Pt-ZnO heterostructure on $\alpha-\mathrm{Al}_{2} \mathrm{O}_{3}$ (0001). J. Cryst. Growth 2006, 291, 212-217. [CrossRef]

36. Liu, J.; Qiao, B.; Song, Y.; Huang, Y.; Liu, J. Hetero-epitaxially anchoring Au nanoparticles onto ZnO nanowires for CO oxidation. Chem. Commun. 2015, 51, 15332-15335. [CrossRef] [PubMed]

37. Tauster, S.J.; Fung, S.C.; Garten, R.L. Strong metal-support interactions. Group 8 noble metals supported on titanium dioxide. J. Am. Chem. Soc. 1978, 100, 170-175.

38. Fu, Q.; Wagner, T. Interaction of nanostructured metal overlayers with oxide surfaces. Surf. Sci. Rep. 2007, 62, 431-498. [CrossRef]

39. Rodriguez, J.A.; Kuhn, M. Chemical and electronic properties of Pt in bimetallic surfaces: Photoemission and CO-chemisorption studies for Zn/Pt(111). J. Chem. Phys. 1995, 102, 4279-4289. [CrossRef]

40. Pan, Z.W.; Dai, Z.R.; Wang, Z.L. Nanobelts of Semiconducting Oxides. Science 2001, 291, $1947-1949$. [CrossRef] [PubMed]

(C) 2016 by the authors; licensee MDPI, Basel, Switzerland. This article is an open access article distributed under the terms and conditions of the Creative Commons Attribution (CC-BY) license (http:/ / creativecommons.org/licenses/by/4.0/). 